\title{
Historical Aspects of the Emergence and Evolution of the Judiciary in Russia
}

\author{
Elena Barasheva \\ Russian State University of Justice \\ Irkutsk, Russia \\ Email: barahevaev@bk.ru
}

\author{
Larisa Dmitrieva \\ Russian State University of Justice \\ Irkutsk, Russia \\ Email: Larisay-nauka@mail.ru
}

\begin{abstract}
The article deals with the judiciary genesis of Russia. This study researches the historical background and the formation ways of the independent judiciary institute, starting from the first decade of the XI century, and ending with the formation of modern Russian justice system in the 90s of the XX century. The author's analysis allows us to trace the patterns of the Russian judiciary transformation throughout its historical course. A historical analysis of the justice system emergence in Ancient Russia and its further development during the reign of Catherine the Great, Alexander II, as well as in the period after the October revolution and its development in the state of a new formation. The concept of judiciary and its meaning "de facto" and "de jure" in the period of Communist power development up to the present time in a democratic state were analyzed. The stages of judiciary formation in Russia since the times of Peter the Great were defined.
\end{abstract}

Keywords - justice system, judiciary, Russian history, judicial reform.

\section{INTRODUCTION}

Russian and foreign historiography has the most widespread point of view according to which the primary official and institutional design of the judiciary's elements (although in a form far from modern ideas about this institution) in Russia took place under Yaroslav the Wise rule. His name is associated with the emergence of the first manuscript set of Russian laws - "Russian truth", which contained, including separate, unsystematic rules on the order of the justice system and legal proceedings (procedural norms) [1]. However, it should be noted that before the appearance of this written source of law and in the subsequent course of history (in some aspects up to the XVII century), the role and functions of the judiciary were connected with and performed by the highest ranks of the parochial system: princes (both specific and great, and after the approval of such a title-and the monarch himself), boyars and other representatives of the most noble positions which helped to administer princely justice.

Of course, it is not possible to determine the exact date of the court in Russia. In general, the researchers believe that the main elements of the justice implementation appeared with Christianity and the Byzantine socio-cultural tradition and socio-political model [2].

\section{METHODS}

The research uses the method of comparative analysis.

\section{RESULTS AND DISCUSSION}

The first mention of the "court" concept is contained in the Charter of the Prince of Novgorod and Kiev Vladimir Svyatoslavovich "on tithes, courts and people of the church", but its exact date of writing is unknown in history. Some mentions of the courts are also contained in the "Tale of bygone years" in the moments describing the signing of a number of treaties between Russia and Byzantium in the $\mathrm{X}$ century [3].

The primary stage of judiciary formation in Russia as a separate government institution was in the reforms of Peter the Great. He believed that effective judicial proceedings should be carried out by bodies and persons not burdened with the other powers of authority (military, legislative or Executive), the role and functions of which would be reduced strictly to the administration of justice. Such bodies were established by Peter Justices-the College and the Senate. The first was a kind of judicial Department which managed the entire array of courts, the second was considered as complex cases, primarily political and affecting the interests of the state at the highest level. Peter the Great, as in the course of his other sociopolitical reforms, wanted to be an example of their implementation as much as possible trying to withdraw from the implementation of justice personally [4].

Another significant element of his reform of the judiciary was the decree "the court form" (issued on November 5, 1723) that was introduced in the principle of adversarial proceedings (although in a very simplified form and often completely leveling the importance and activity of the defense) that was a significant achievement of the time for the Russian power. However, we must admit that such reforms occurred in our country rather late in comparison with a number of European countries of the same historical epoch.

An important reform in the justice system of Russia was the transformation of Catherine the Great who introduced a system of class courts: dispute resolution and punishment of landlords belonged to the jurisdiction of the upper Zemstvo courts and County courts, state peasants-to the upper punishment in specific administrative entities (provinces or counties), personally free citizens - to the magistrates [5]. The function of the highest "instance" was still performed by the Senate whose power in the provinces were delegated to the criminal and civil chambers. As before, the role of specific persons from among the highest nobility remained extremely important in the administration of justice, which blurred the 
emerging principle of power separation. So the monarch personally determined and influenced on the consideration of cases by the Senate, and the sentences of the judicial chambers "on the ground" were often dictated by the will of governors and the interests of influential boyars and nobles.

In 1802-1803 (the first stage) and 1810-1811 (the second stage) in the Russian Empire, M. M. Speransky and the "Secret Committee" under Emperor Alexander I was reformed into the ministries. The Ministerial reform abolished the obsolete boards, transferring them to a new status of ministries. For the judiciary, it has been resulted in the control transfer over the civil and criminal courts to a newly established Ministry of justice [6].

In the first half of XIX century the Ministry of justice is most concerned about the improvement of records management in the Senate, as well as the development of bills aimed at organizing and improving the efficiency of the Russian Empire justice system. During the same period a project for reorganization of the Governing Senate was developed that provided the creation of two independent institutions: the Governing Senate and the Judicial Senate that could radically change the historical fate of the Ministry of justice that began to form as a body of the justice system. According to the draft, the judicial Senate was to become the highest body of the justice system and court in the Russian Empire having Worked through all the points of discussion, the project was approved, but its practical implementation did not take place because "favorable circumstances" were not arisen. By that time the activities of the Ministry of justice began to have more and more new forms and methods of influence on the justice system that were firmly established not only in the Ministry of justice of the Russian Empire but corresponding Ministry of temporary subordination. The Government, and in the subsequent People's Commissariat of justice (ministries) of the RSFSR (USSR). One of such methods was to conduct inspections in the courts to identify "deficiencies in the processing of documents and to find ways how to eliminate them."

Thus, the Ministry of justice of the Russian Empire struggled with red tape, arbitrariness and abuses in the judiciary. Judicial administration still in the form of a "justice system" was further developed during the judicial reform of 1864. Despite the fact that the decree on the implementation of the judicial Charter provided the purpose of judicial reform "to create a fast, fair court, gracious and elevating the judiciary with due independence". However, it was a somewhat declarative statement since the Ministry of justice was entrusted with Supervisory functions, as well as dealing with the staffing of the courts, with the appearance in the structure of the judiciary of magistrates, congresses of magistrates (appeals to district magistrates) and township ranks, called local courts, the Ministry of justice that is carried out jointly with the government of the Senate and its cassation departments were also under general supervision. In General, justices of the peace, the President of the Congress of justices of the peace, and an indispensable member were elected but in the suburbs and colonial districts they were appointed by the Minister of justice [7] in 1870, the Minister of justice obtained the right to appoint investigators to each district court for special cases.

With the beginning of the amendment of the judicial Charter, on the recommendation of the Minister of justice, a special joint presence of the first and cassation departments was formed in the Senate to monitor judicial decisions and officials of the judicial Department. The particular attention was paid to the trial of judges at all levels (the world, the city, the district, the presidents and members of the chambers, prosecutors, jurors for breach of duty), the resumption of criminal cases, disputes on jurisdiction, complaints and protests against court decisions were considered by the chambers and others. (In part, such powers belong to the presidencies and qualification colleges of the modern justice system). It should be noted that the activities of the Special liaison were described as nothing more than "judicial administration". Despite the strengthening of the position of the Ministry of justice in the justice system, the Senate has continued to be not only the highest judicial body but also the authority to oversee the rule of law, including in the judiciary.

In 1885 the highest disciplinary presence was formed in the Senate to deal with disciplinary offenses of officials of the judicial Department that remained after the February revolution of 1917 but only in the form of a temporary Supreme disciplinary court of the Senate [4]. The adoption of relevant legislation increases the status of the Minister of justice and expands his powers. From that moment he was authorized to initiate disciplinary proceedings against judges and judicial officials [8] only with his recommendations it should be done the cases of misconduct of judges and inaction in the service that do not entail removal from office in the court but indicate the inconsistency of the judge of his official position, be considered in a more strict disciplinary procedure. In addition, the Minister of justice could raise the issue of dismissal of judges who have committed reprehensible acts. Both during the service and outside it, which is incompatible with the "dignity of the judicial rank" [5].

A significant moment in the history of the domestic justice system was the transformation that occurred with the introduction of Alexander II such important acts of law as "the Establishment of judicial institutions", "the Statute of penalties imposed by magistrates", "the Statute of criminal proceedings" and "the Charter of civil proceedings". The result of their adoption was, firstly, the division of courts into three stages: the magistrate's court, the district court and the judicial chambers-each with a strictly defined jurisdiction and jurisdiction. In the highest degree it is important that these courts henceforth did not bear class (class) character, and were uniformed for all submitted to the Empire. Secondly, these statutes prescribed the unshakable principles of criminal and civil proceedings: the transparency of proceedings and the adversarial nature of the parties, the independence of the court and the irremovability of judges. Such fundamental institutions of legal proceedings as the Institute of attorneys (lawyers), prosecutors and jurors were established [9].

The result of the reforms was the allocation of the judiciary as a conditionally independent branch of government of the Russian Empire with its own hierarchy (jurisdiction). The 
Government Senate continued to act as the highest (cassation) instance. According to the establishment of judicial institutions of November 20, 1864, the judiciary belonged specifically to the jurisdiction of the previously listed courts that thus consolidated the very concept and existence of this institution in Russia at the official legislative level.

However, the General trend of concentration and administration of real judiciary in the hands of the highest state officials continued. Despite the absence of formal and legal consolidation of the fullness of judiciary in the hands of the head of state, the monarch was universally recognized and was the highest judicial "instance" in any case that could be of interest to him (although, for the most part, such interest affected only high-profile political cases affecting the state interests at the highest level). The Emperor exercised such power not only directly by his decisions, but also indirectlythrough other judicial bodies: first of all, through the Senate (despite the fact that with the establishment of the statutes, which we have written earlier, it was expressly prescribed that the judiciary should be assigned to the established system of courts) [2]. The Monarch signed legislative acts, approved and discharged the duties of judges, authorized the execution of death sentences, and the justice system existing within the established framework of strict normalism did not possess either the full ability to normalize the legislative power, nor the necessary tools for the comprehensive protection of human rights in the face of arbitrariness on the part of administrative and Executive bodies [10].

In this case, we have to admit that the emergence in the sphere of Russian law of the concept of "judiciary" and its formal legal consolidation in the legislative body, does not indicate the actual emergence of an independent branch of government. In many ways, the implementation of the above reforms was dictated by both the internal and foreign policy situation of the Russian Empire. Thus, summarizing the considered historical period, we can speak rather about the judiciary concentrated in the hands of a certain number of persons (the monarch and the highest nobility) and bodies which carried out the legal proceedings authorized by such persons, rather than about really original, independent branch of power in the state [11].

With the completion of the October revolution and the formation of a new state-the USSR, a new legal order began to operate on the territory of our country. It should be noted that the changes in the legal appearance of the state have had an ambiguous impact on the justice system of Russia. In this historical period, on the one hand, the attitude towards the court was formed as another (in a number of other) instrument of class struggle, which was designed to continue and transmit to society the will of the ruling class, to protect its interests and to continue and strictly adhere to the policy of the dominant Communist party. Thus, the courts were not an independent branch of government, but acted as a statebureaucratic system of bodies, an institution subordinated to the political interests of society [12].

The principle of separation of powers was completely rejected by the Communist ideology, because it was bourgeois, and because of this quality alone it was regarded as absolutely untenable. The state was considered by theorists of the Communist school as a kind of" working Corporation", which was based on the Soviets of people's deputies. Since managerial actions require certain qualifications from the performers, in the conditions of division of labor, the activity of Councils, and especially Executive committees, has always been replaced by the work of their apparatuses. One such apparatus was the court.

The scope of its activity in the conditions of the supremacy of the party-state machine was narrowed to the consideration of criminal cases, as well as civil cases arising mainly from marriage and family relations. Other conflict situations were practically not considered by the courts, because they were within the competence of other state-party structures [13].

Despite the fact that under the Civil procedure and Criminal procedure codes in the period from 1923 to 1991, the Soviet judges obeyed only the laws, the official orientation of the courts to "strengthen the state and political system" led to the devaluation of the said key principle of legal proceedings. Court decisions did not go beyond the current policy of the state.

This does not mean that most of them were not in the best interests of society. The stability of the vast majority of decisions taken during the Soviet period clearly indicates that in the main they met not only the criteria of legality and validity, but also justice [14].

\section{CONCLUSION}

Restoration of independence and independence of the justice system in Russia began in the early 90s of the last century. This is largely due to the rejection of the communist ideology of society. A lot has been done in this direction, but at the present time it is only with sufficient caution that we can say that this process is successful, and even closer to completion [15].

The achievements of the second judicial reform, in our opinion, are limited mainly to the official recognition and legislative consolidation of the principle of competition in all types of proceedings and the improvement of the financing of the justice system. At the same time, another thing is obvious: the mechanism of checks and balances in our country (article 10 of the Constitution of the Russian Federation) is largely declarative [16]. However, such a state of Affairs is not unexpected in a society that knew only one form of government - a pyramid of officials, crowned almost by a deity, for such a short time the corps of independent subjects of judicial and power relations could not be formed. Since the judiciary is, first of all, a social value, and not the laws, our country has yet to determine its place among other socially important institutions of society.

\section{References}

[1] A. Alekseev, Russian state law, 1946.

[2] V.A. Kitaev, "How many faces does Russian liberalizm have?", Liberation movement in Russia, vol. 22, pp. 180-192, 2007.

[3] M.F. Vladimirskiy-Budanov, Review of the Russian law history, 2001, pp.752-754. 
[4] Resolution of Supreme Court by 24.10.1991, № 1801-1, “On the Concept of judicial reform in the RSFSR", vol. 44, art. 1435, 1991.

[5] V.V. Shelohaev, "Debatable problems of the Russian liberalism history in the modern historical literature", Historical questions, vol. 5, pp. 3-17, 2007.

[6] N.V. Splavskaya, V.I. Gorokhova, "Prospects for the development of the legal state in Russia", State and law in the $21^{\text {st }}$ century, vol. 2, pp. 5-11, 2015 .

[7] N.B. Khailova, A. Chuprov Russian, Liberalism of the mid XVIII early XX, 2010

[8] V.V. Shelohaev, On various topics, 2016.

[9] T. L. Kuras, "Reforming of the judicial system in Russia: history and modernity", Power, vol. 10 (22), pp. 145-150, 2014.
[10] R.A. Arslanov, V.V. Blokhin, "Intelligentsia in views of Russian liberals and reformers-democrats of late XIXth - the early XXth centuries", Rudn Journal of Russian History, vol. 2, pp. 22-37, 2014.

[11] V.I. Vlasov, History of the judiciary in Russia, 2003.

[12] A.M. Gradovskiy, The beginning of Russian state law, 2011.

[13] R.A. Arslanov, V.V. Blokhin, "Intelligentsia in views of Russian liberals and reformers-democrats of late XIXth - the early XXth centuries", Rudn Journal of Russian History, vol. 2, pp. 22-37, 2014.

[14] O.E. Kutafin, V.M. Lebedev, G.Yu. Semigin, Judiciary in Russia: history, documents, 2003.

[15] R.A. Arslanov, K.D. Kavelin, Chelovek i myslitel, 2000.

[16] M.V. Kozhevnikov, History of the Soviet court (1917 - 1956 years), 2011, pp. 3. 